\title{
Protection of lead in an environment containing acetic acid vapour by using adsorbents and their characterization
}

\author{
Sarka Msallamova* (D, Milan Kouril, Kristyna Charlotte Strachotova, Jan Stoulil, Kateryna Popova, \\ Pavla Dvorakova and Miloslav Lhotka
}

\begin{abstract}
Historical museums and depositories contain collections with a number of lead objects or historical documents with lead seals. Lead is a metal which has good corrosion resistance under atmospheric conditions. On the other hand, lead corrodes in an activity in an environment which contains volatile organic compounds (mainly acetic acid and formic acid). In a depository environment, sources of volatile compounds can be the historical documents themselves, wood, plastics (those made from cellulose acetate), polyvinyl acetate adhesives, varnishes, oil or emulsion paints, etc. The aim of this work was to compare the efficiency of commercial adsorbents (activated carbon, activated alumina, zeolite, and bentonite) in the acetic acid vapours. The lead corrosion rates were determined by using lead resistometric probes. Activated alumina and activated carbon were found to be the most effective adsorbents of acetic acid vapours. On the other hand, the available zeolite had the worst sorption ability compared with the other tested substances.
\end{abstract}

Keywords: Lead, Adsorption, Acetic acid, Activated alumina, Activated carbon, Zeolite, Bentonite, Resistometric probe

\section{Introduction}

Historical museum collections contain a number of lead objects that, among other things, also contain historical documents with lead seals. These objects and historical documents are frequently stored under conditions in museum depositaries where volatile organic compounds are released. The sources of these volatile organic compounds in depositaries are unsuitable packaging materials, wood, unsuitable coatings and adhesives and also the historical documents themselves [1].

Lead is an amphoteric metal. The good corrosive resistance of lead under atmospheric conditions is ensured by the formation of a passive layer with a thickness of 3-6 nm on its surface [2]. The passive layer consists predominantly of $\alpha-\mathrm{PbO}[2,3]$. The mechanism of the lead corrosion process under atmospheric conditions is described by the following equations [4]:

*Correspondence: msallams@vscht.cz

University of Chemistry and Technology, Prague, Czech Republic
Anodic oxidation: $\mathrm{Pb}^{0} \rightarrow \mathrm{Pb}^{2+}+2 \mathrm{e}^{-}$

Cathodic reduction: $1 / 2 \mathrm{O}_{2}+\mathrm{H}_{2} \mathrm{O}+2 \mathrm{e}^{-} \rightarrow 2 \mathrm{OH}^{-}$

Formation of $\mathrm{PbO}: \mathrm{Pb}^{2+}+2 \mathrm{OH}^{-} \rightarrow \mathrm{PbO}+\mathrm{H}_{2} \mathrm{O}$

The passive lead layer forms a barrier between the metal and the surrounding environment and thus slows the corrosion reaction. On the other hand, the passive layer is susceptible to dissolution in polluted atmospheric conditions. Depending on the content of atmospheric pollutants, lead further corrodes and forms more stable corrosion products [3].

The insoluble corrosion products of lead that most frequently form a continuous layer on its surface include the compounds $\alpha$ - $\mathrm{PbO}, \mathrm{PbCO}_{3}$ (cerussite), $\mathrm{Pb}_{3}\left(\mathrm{CO}_{3}\right)_{2}(\mathrm{OH})_{2}$ (hydrocerussite) and $\mathrm{Pb}_{10}\left(\mathrm{CO}_{3}\right)_{6} \mathrm{O}(\mathrm{OH})_{6}$ (plumbonacrite) and $\mathrm{PbSO}_{4}$ (anglesite). In a maritime atmosphere the lead corrosion products of lead can also contain $\mathrm{PbCl}_{2}$ 
and $\mathrm{PbCl}(\mathrm{OH})$ (laurionite) [5]. In a strongly reducing $\mathrm{H}_{2} \mathrm{~S}$-containing environment, such as bog or pore electrolytes, $\mathrm{PbS}$ can be also found in lead corrosion products [3]. All the above compounds are stable components of lead corrosion products. Under atmospheric conditions, they do not participate in further active corrosion damage of the lead matrix [2].

Active lead corrosion takes place in the presence of volatile organic acids in the atmosphere, where non-cohesive soluble corrosion products are formed on the surface of the lead (e.g. lead formate or lead acetate etc.). Lead corrosion rate in an environment with the content of formic acid is lower than lead corrosion rate in an environment with the content of acetic acid [3, 4]. According to Coles lead corrosion rate in dilute aqueous solutions of propionic, butyric, succinic and lactic acid is comparable to lead corrosion rate in dilute of acetic acid [6]. On the other hand, organic acids with a longer carbon chain, such as pyruvic, oxalic or tartaric acid, passivate a lead surface and the corrosion rate is lower than the corrosion rate for the above mentioned organic acids with a shorter carbon chain [6, 7]. A basic condition for active corrosion of lead by the action of acetic acid is the elevated relative humidity, where a thin layer of electrolyte is formed on the surface of the metal, in which volatile organic acids from the surrounding environment are dissolved [8]. The acidified electrolyte penetrates into cracks and defects in the protective corrosion layer, mostly consisting of $\alpha-\mathrm{PbO}, \mathrm{PbCO}_{3}$ and $\mathrm{Pb}_{3}\left(\mathrm{CO}_{3}\right)_{2}(\mathrm{OH})_{2}$ and reacts with the lead to form soluble lead acetate [9]. Acetic acid acts as a catalyst of the reaction $[10,11]$. The mechanism of corrosive attack on lead in a damp atmosphere containing acetic acid is described by the following equations [12]:

$$
\mathrm{Pb}+2 \mathrm{CH}_{3} \mathrm{COOH}+1 / 2 \mathrm{O}_{2} \rightarrow \mathrm{Pb}\left(\mathrm{CH}_{3} \mathrm{COO}\right)_{2}+\mathrm{H}_{2} \mathrm{O}
$$

$$
\begin{aligned}
& 3 \mathrm{~Pb}\left(\mathrm{CH}_{3} \mathrm{COO}\right)_{2}+2 \mathrm{CO}_{2}+4 \mathrm{H}_{2} \mathrm{O} \\
& \quad \rightarrow \mathrm{Pb}_{3}\left(\mathrm{CO}_{3}\right)_{2}(\mathrm{OH})_{2}+6 \mathrm{CH}_{3} \mathrm{COOH}
\end{aligned}
$$

$\mathrm{PbO}$ dissolves in an environment with content of acetic acid to form $\mathrm{Pb}\left(\mathrm{CH}_{3} \mathrm{COO}\right)_{2} \cdot 2 \mathrm{PbO} \cdot \mathrm{H}_{2} \mathrm{O}$ according to the following mechanism [13]:

$$
\mathrm{PbO}+2 \mathrm{CH}_{3} \mathrm{COOH} \rightarrow \mathrm{Pb}^{2+}+2 \mathrm{CH}_{3} \mathrm{COO}^{-}+\mathrm{H}_{2} \mathrm{O}
$$

$$
\begin{gathered}
2 \mathrm{PbO}+\mathrm{Pb}^{2+}+2 \mathrm{CH}_{3} \mathrm{COO}^{-}+\mathrm{H}_{2} \mathrm{O} \\
\rightarrow \mathrm{Pb}\left(\mathrm{CH}_{3} \mathrm{COO}\right)_{2} \cdot 2 \mathrm{PbO} \cdot \mathrm{H}_{2} \mathrm{O}
\end{gathered}
$$

Elimination of the active corrosion of lead requires elimination the source of volatile organic acids from the environment. Storage space formed by material other than wood is necessary for long-term storage of lead objects and paper packaging material with an alkaline reserve should be used. Some types of adhesives, oilbased or emulsion colours or unsuitable joining materials could be another source of volatile organic acids. The use of corrosion inhibitors, destimulators and adsorbents provide further means for protection of lead objects against the action of volatile organic acids [14-16]. The metal-organic frameworks (MOFs) for removal of low concentration of acetic acid from the environment are reported, too. The MOFs which haven't the polar groups in the inorganic nodes or have polar lipophilic groups in the organic chains are more successful at the removal of acetic acid from the environment [17].

The use of adsorbents is one of options which would prevent the presence of volatile organic acids in enclosed spaces of depositaries where it is not technically possible to completely eliminate the source of the volatile organic substances. Adsorbents are materials with high sorption ability for gases or liquids. They are usually used in the form of spherical particles, rods or fragments with a size between 0.5 and $10 \mathrm{~mm}$. The effectiveness of the adsorbent is affected by a number of external parameters, such as temperature and relative humidity of an environment, concentration of pollutants or ventilation. The internal parameters comprise primarily the properties of the sorbents, such as polarity, specific surface area and porosity $[18,19]$. Their adsorption ability is a result of their large specific surface area, which is determined by their structure. As the number increases, the area accessible for adsorption and thus the sorption capacity also increase. Pores are distinguished as micropores with diameter of less than $2 \mathrm{~nm}$, mesopores with diameter from 2 to $50 \mathrm{~nm}$ and macropores with diameter greater than $50 \mathrm{~nm}$ $[20,21]$.

The aim of this work is to compare the adsorption effectiveness of selected commercial adsorbents and to find the best adsorbent of acetic acid vapours for a museum depositary environment in which historical documents with lead seals or other lead objects in collections are stored for long periods of time. Characterization of selected commercial adsorbents, which were used for this experiment, was also the part of this work.

\section{Experimental}

Five commercial adsorbents activated carbon (type NCP 15-65, Ercopol, s.r.o.), activated alumina (type ESM 143, Eco-Aqua-Servis, s.r.o.), bentonite (type Eiwex granulate, Kobern s.r.o.), bentonite with activated carbon (the surface of bentonite granules are covered with an activated carbon layer) (type Most-Rein ${ }^{\circledR}$ PORETEC, Erbsloh Geisenheim, GMBH) and zeolite (fraction 1-2.5 mm, Subio Eko, s.r.o.) were selected for the experiment. All of them are applicable for the sorption of 
low concentrations of acetic acid vapours in a museum depositary environment. Characteristics of the sorbents are described in chapter 3.1. All the employed adsorbents were in granulated form. The 1-2 $\mathrm{mm}$ fractions were used for the experiment. Adsorbents prepared in this way were dried at a temperature of $105^{\circ} \mathrm{C}$ for $4 \mathrm{~h}$ before using in the experimental cells.

The phase composition of adsorbents was determined by XRD diffractometer PANanalytical X'Pert ${ }^{3}$ Powder with $\mathrm{CuK} \alpha$ radiation $(\lambda=1.5418 \AA, \mathrm{U}=40 \mathrm{kV}, \mathrm{I}=30 \mathrm{~mA})$ in the angular range $5-90^{\circ} 2 \theta$, step size of $0.08^{\circ}$, and counting time of $120 \mathrm{~s} \mathrm{step}^{-1}$. The XRD patterns were evaluated using the commercial software PANanalytical X'Pert HighScore Plus 4.5 (chapter 3.1.1).

The particle size of the adsorbents was documented by transmission electron microscopy EFTEM Jeol 2200 FS with $\mathrm{ZrO} / \mathrm{W}$ Shottky electron emitter (chapter 3.1.2).

Determination of the specific surface area requires measurement of the adsorption isotherm. The BET (Brunnauer, Emmet and Teller) equation is one of the most frequently used equations describing the calculation of the specific surface area. The BET theory is an extended Langmuir theory and is valid for a multi-layer adsorbent. The BET equation assumes that the first layer of the adsorpt (usually nitrogen, argon or carbon dioxide) is adsorbed according to the Langmuir theory and that further layers of adsorpt have the properties of a liquid [20]. The ASAP 2020 Micromeritics instrument was used to measure the adsorption isotherm (chapter 3.1.3).

The mercury porosimetry method was used to determine the adsorbent pore size distribution. The method is based on increasing the pressure of a hydrophobic intrusion liquid and gradual filling of the pores from the largest to the smallest. The instrument works in two regimes (low pressure regime to a maximum pressure of $0.3-0.4 \mathrm{MPa}$ and high-pressure regime to a maximum pressure of $414 \mathrm{MPa}$ ). This method enables determination of the distribution of macro and mesopores from 2 to $1 \mathrm{~mm}$ in size [21]. The AutoPore IV 9500 Micromeritics mercury porosimeter was used to measure the pore distribution (chapter 3.1.4).

The effectiveness of adsorption of acetic acid vapours of selected adsorbents was determined using resistometric probes (chapter 3.2). Glass cells were used in the experiment (Fig. 1). The corrosive environment was modelled using an acetic acid solution $\mathrm{c}=0.01 \mathrm{~mol} \mathrm{dm}^{-3}$. The acetic acid solution was placed at the bottom of a glass cell under a glass frit (Fig. 1). The adsorbent was placed in the lower part of the cell on the glass frit and weighed $20 \mathrm{~g}$ prior to exposure. The sorption effectiveness was determined by monitoring the corrosion rate of a lead by resistometric probe placed in the cell above the glass

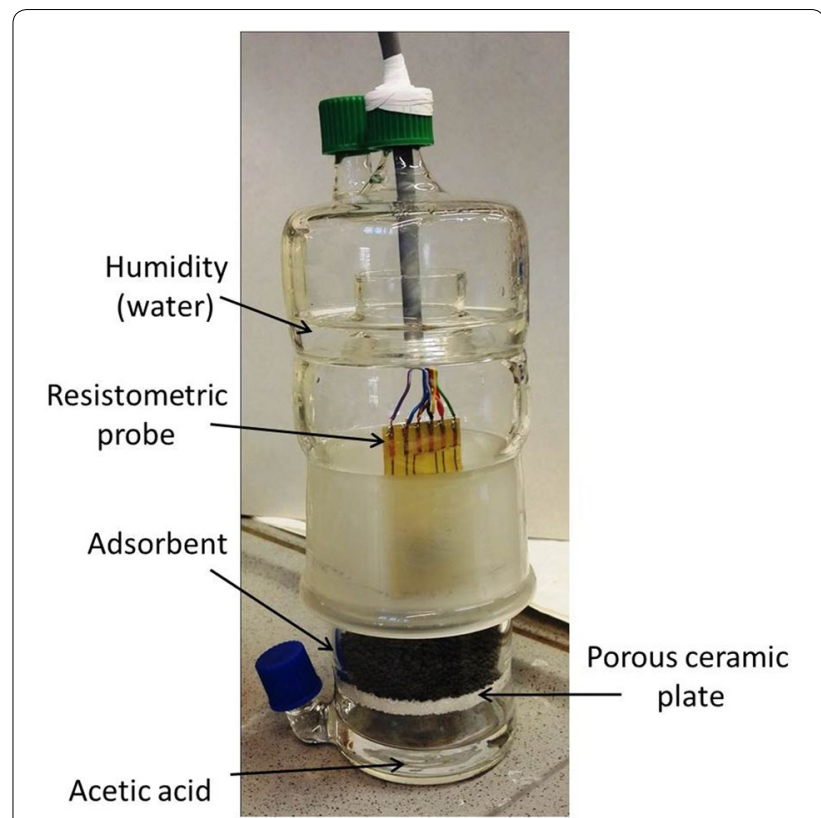

Fig. 1 Experimental glass cell

frit with the adsorbent (Fig. 1). The test was accelerated by RH $100 \%$ (distilled water in the upper part of the glass cell). The lead resistometric probes in the individual cells were connected to a Keithley 3706A measuring switchboard. The exposure time was 28 days minimally at room temperature.

The resistometric probe consists of measurement and reference parts. A lead trace with an initial thickness of $25 \mu \mathrm{m}$ is located on the polymer support. The resistometric probe was made from lead sheeting with a composition of $\mathrm{Pb} 97 \mathrm{wt} \%$, Sn $1.5 \mathrm{wt} \%$ a Sb1.5 wt\% (producer-Goodfellow). The reference part of the probe was taped over with a protective strip of $3 \mathrm{M}$ Solar Ultra Barrier Film (Fig. 2).

The resistometric method determines the corrosion rate in the metal trace in dependence on a change in the electrical resistance.

$$
R=\rho \frac{l}{S} \cdot=\rho \cdot \frac{l}{h \cdot w}
$$

l-length of the metal trace, $\mathrm{h}$-thickness of the metal trace, $\mathrm{w}$-width of the metal trace, $\rho$-resistivity, $\mathrm{R}$ electrical resistance.

Loss of lead thickness can then be calculated using the following formula [22].

$$
\Delta h=h_{0} \cdot\left(1-\frac{R_{R}}{R_{M}} \cdot \frac{R_{M, 0}}{R_{R, 0}}\right)
$$




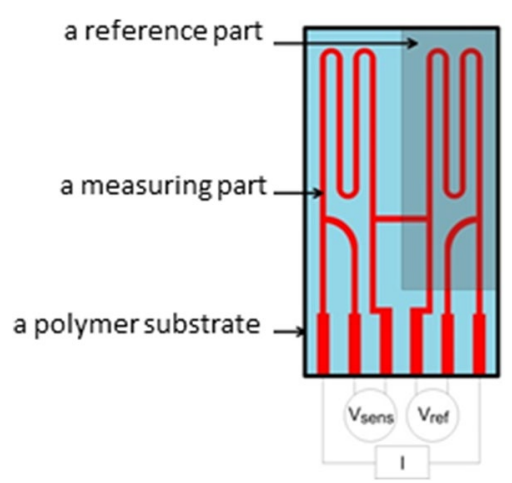

Fig. 2 Resistometric probe [22]

$\mathrm{h}_{0}$-initial thickness of the metal trace, $\mathrm{R}_{\mathrm{M}, 0}$-initial electrical resistance of the measuring part, $R_{R, 0}$-initial electrical resistance of the reference part, $R_{M}-$ momentary electrical resistance of the measuring part, $R_{R}-$ momentary resistance of the reference part.

The corrosion rate is the derivative of the decrease in the thickness by time $\left(v_{k}=\frac{d h}{d t}\right)$. The corrosion rate of lead was evaluated as the slope of the regression straight line in a selected section of the recording of the decrease in the thickness [23].

\section{Results and discussion}

Characteristics of the sorbents

$X$-ray diffraction analysis

Activated carbon contains a majority share of amorphous phase with a small amount of impurities $\mathrm{SiO}_{2}, \mathrm{Fe}_{3} \mathrm{O}_{4}$, $\mathrm{FeAl}_{2} \mathrm{O}_{4}$ and $\mathrm{Al}_{2} \mathrm{CaO}_{8} \mathrm{Si}_{2}$.

Activated alumina contains a majority share of $\gamma \mathrm{Al}_{2} \mathrm{O}_{3}$. Possible impurities are below the detection limit of the instrument.

Bentonite contains a majority share of $(\mathrm{Na}, \mathrm{Ca})_{0.3}(\mathrm{Al}$ , $\mathrm{Mg})_{2}\left(\mathrm{Si}_{4} \mathrm{O}_{10}\right)(\mathrm{OH})_{2} \cdot \mathrm{nH}_{2} \mathrm{O}$ with a small amount of $\mathrm{SiO}_{2}$, $\mathrm{NaAlSi}_{3} \mathrm{O}_{8}, \quad(\mathrm{~K}, \mathrm{Na})(\mathrm{Al}, \mathrm{Mg}, \mathrm{Fe})_{2}\left(\mathrm{Si}_{3.1} \quad \mathrm{Al}_{0.9}\right) \mathrm{O}_{10}(\mathrm{OH})_{2}$, $\mathrm{Al}_{2} \mathrm{Si}_{2} \mathrm{O}_{5}(\mathrm{OH})_{4}$ and $\mathrm{KAlSi}_{3} \mathrm{O}_{8}$.

Bentonite with activated carbon has the same composition as the bentonite mentioned above, and the surface of bentonite granules are covered with an amorphous layer in this case.

Zeolite contains a majority share of $(\mathrm{Na}, \mathrm{K}, \mathrm{Ca})_{5} \mathrm{Al}_{6} \mathrm{Si}_{30} \mathrm{O}_{72} \cdot 18 \mathrm{H}_{2} \mathrm{O}$ with a small amount of $\mathrm{SiO}_{2}$, $\mathrm{NaAlSi}_{3} \mathrm{O}_{8}$ and $(\mathrm{K}, \mathrm{Na})(\mathrm{Al}, \mathrm{Mg}, \mathrm{Fe})_{2}\left(\mathrm{Si}_{3.1} \mathrm{Al}_{0.9}\right) \mathrm{O}_{10}(\mathrm{OH})_{2}$.

The diffraction pattern of adsorbents is shown in Fig. 3.

\section{Transmission electron microscopy (TEM)}

As shown in Fig. 4a-c, the activated alumina is formed of elongated particles with an approximate diameter of $4-5 \mathrm{~nm}$. The average length of the particles is $20 \mathrm{~nm}$.

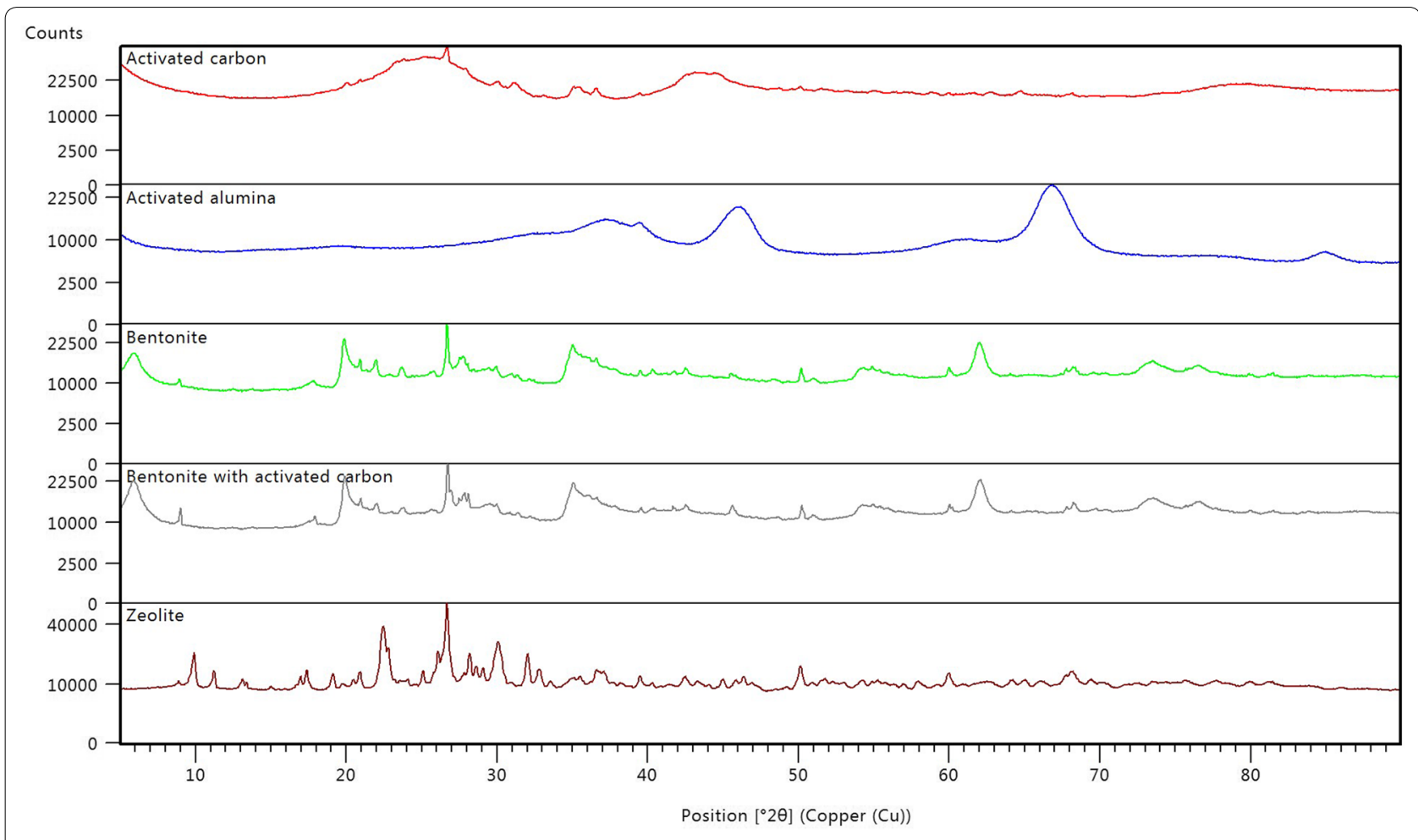

Fig. 3 The diffraction pattern of adsorbents 


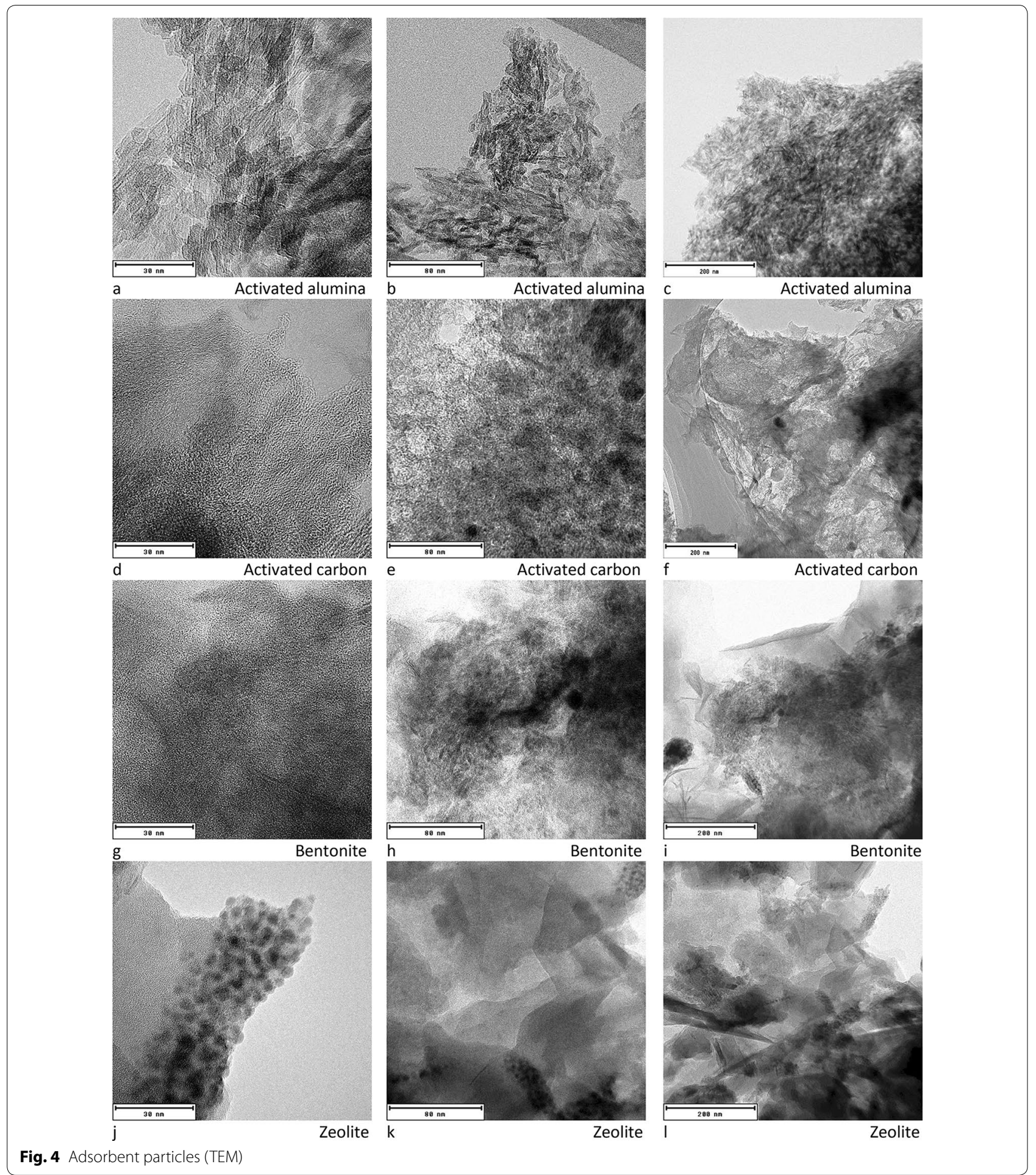

Activated carbon is formed of conglomerates of very fine elongated particles; see Fig. 4d-f. The particles dimension could not be measured. The bentonite particles also have an elongated shape (Fig. 4h) but are not so fine in comparison with activated carbon; see Fig. $4 g-i$. The bentonite is also formed of conglomerates and therefore the dimensions of the particles could not be measured. Zeolite is formed of irregular particles; see Fig. 4k, 1 . The average size of particles is $180-200 \mathrm{~nm}$. In the zeolite particle mixture, is also present a small number of 
spherical particles with an approximate diameter $5 \mathrm{~nm}$; see Fig. 4j.

\section{BET method}

The adsorption isotherms of nitrogen were used to compare the individual adsorbents from the viewpoint of the specific surface area, particularly of the micro- and mesopores (Fig. 5).

It follows from the shape of the adsorption isotherm (Type Ib-classification of IUPAC) [24] that activated carbon is material with microporous structure. The adsorption isotherm of activated carbon has classical type hysteresis loop H4 (IUPAC classification) [24], which corresponds to slit pores. On the other hand, activated alumina, bentonite and zeolite are mesoporous materials with a small contribution of micropores (Type IVa-classification of IUPAC) [24] (Fig. 5). Alumina, zeolite and bentonite samples consist of micropores and mesopores with type hysteresis loops $\mathrm{H} 2 \mathrm{a}$ and $\mathrm{H} 2 \mathrm{~b}$ (IUPAC classification) [24], which correspond to more complex pore structures. The specific surface area (Asp BET) of activated carbon was found $809.7 \mathrm{~m}^{2} \mathrm{~g}^{-1}$, but the specific surface area (Asp t-plot) was $229.3 \mathrm{~m}^{2} \mathrm{~g}^{-1}$, i.e. the sample contains a significant part of micropores. The specific surface area (Asp BET) activated alumina, bentonite and zeolite was found $247.2 \mathrm{~m}^{2} \mathrm{~g}^{-1}, 52.1 \mathrm{~m}^{2} \mathrm{~g}^{-1}$ and $15.2 \mathrm{~m}^{2} \mathrm{~g}^{-1}$, but the specific surface area (Asp t-plot) was $231.2 \mathrm{~m}^{2} \mathrm{~g}^{-1}, 35.1 \mathrm{~m}^{2} \mathrm{~g}^{-1}$ and $11.5 \mathrm{~m}^{2} \mathrm{~g}^{-1}$, respectively. Survey of the specific surface areas of the adsorbents are shown in Table 1.
Table 1 The specific surface areas of the adsorbents

\begin{tabular}{lcl}
\hline Adsorbent & $\begin{array}{l}\mathbf{A}_{\mathbf{s p}} \text { of pores to } \mathbf{2} \mathbf{~ n m} \\
{\left[\mathbf{m}^{\mathbf{2}} \mathbf{g}^{-\mathbf{1}}\right]}\end{array}$ & $\begin{array}{l}\mathbf{A}_{\mathbf{s p}} \text { of } \mathbf{2}-\mathbf{5 0} \mathbf{~ n m} \\
\text { pores }\left[\mathbf{m}^{\mathbf{2}} \mathbf{~ g}^{-\mathbf{1}}\right]\end{array}$ \\
\hline Activated carbon & 809.7 & 229.3 \\
Activated alumina & 247.2 & 231.2 \\
Bentonite & 52.1 & 35.1 \\
$\begin{array}{l}\text { Bentonite with activated } \\
\quad \text { carbon }\end{array}$ & 107.8 & 54.1 \\
Zeolite & 15.2 & 11.5 \\
\hline
\end{tabular}

\section{Mercury porosimetry}

It follows from the determination of the size distribution of meso- and macropores that the largest distribution is exhibited by activated alumina, between 5 and $10 \mathrm{~nm}$ of diameter. Compared with activated alumina, zeolite has a much smaller content of mesopores, between 50 and $60 \mathrm{~nm}$ of diameter. Both of the above adsorbents contain a minimal number of macropores. Activated carbon contains macropores an average size of approx. $1 \mu \mathrm{m}$ and micropores (diameter below $2 \mathrm{~nm}$ ). Bentonite and bentonite with activated carbon contain macropores with size approx. $5 \mu \mathrm{m}$ (Fig. 6).

The porosity of adsorbents is shown in Table 2 .

\section{Determination of sorption ability of the adsorbents using the resistometric lead probes}

The resistometric method was used to determine the rate of lead corrosion by acetic acid vapours $(\mathrm{RH}=100 \%)$ when adsorbents were used. For comparison, the corrosion rate of lead was also monitored in media of

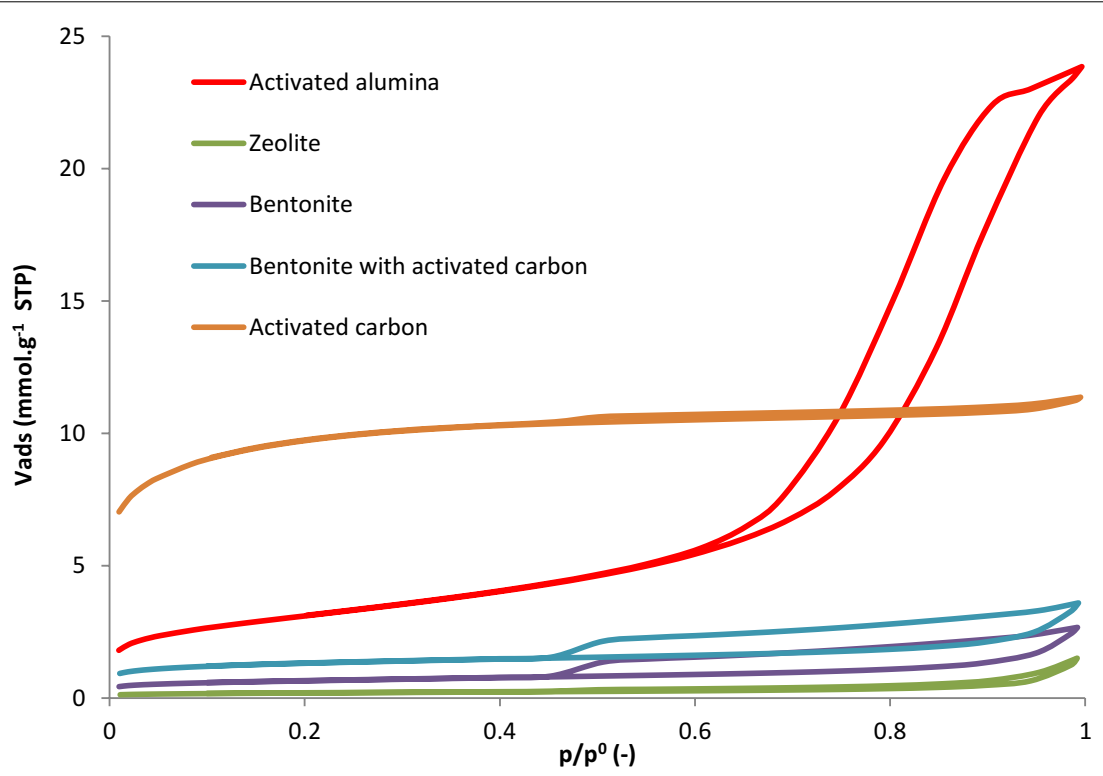

Fig. 5 Comparison of the adsorbents using the adsorption isotherms (BET) 


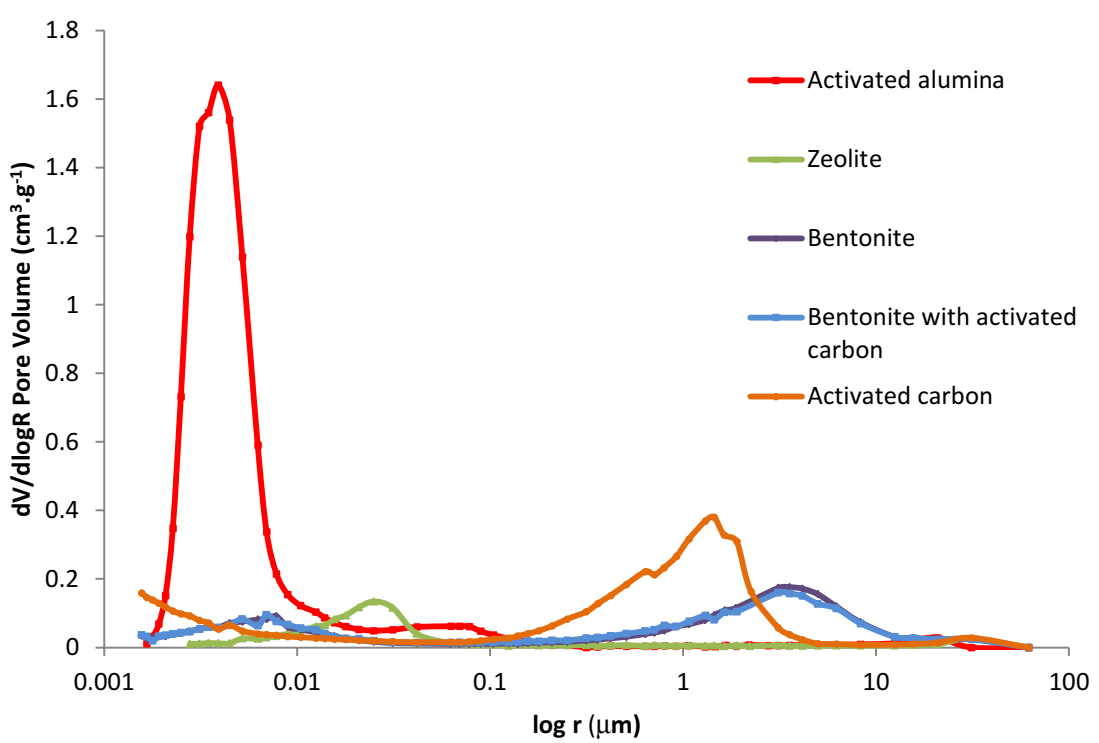

Fig. 6 The size distribution of meso and macropores in the adsorbents (Mercury porosimetry)

Table 2 Porosity of adsorbents

\begin{tabular}{ll}
\hline Adsorbent & $\begin{array}{l}\text { Meso- } \\
\text { and macropores } \\
{[\%]}\end{array}$ \\
\hline Activated carbon & 33.6 \\
Activated alumina & 68.2 \\
Bentonite & 36.8 \\
Bentonite with activated carbon & 35.9 \\
Zeolite & 18.9 \\
\hline
\end{tabular}

$\mathrm{RH}=100 \%$ and $\mathrm{RH}=100 \%+$ acetic acid vapours without using adsorbents. The results of the corrosion rate measurement of lead are summarised in Table 3.

It follows from the measured values that the best adsorption ability in acetic acid vapours has activated alumina $\left(\mathrm{v}_{\text {corr }}=3.7 \times 10^{-4} \mathrm{~mm} \mathrm{a}^{-1}\right)$ and activated carbon $\left(\mathrm{v}_{\text {corr }}=1.5 \times 10^{-3} \mathrm{~mm} \mathrm{a}^{-1}\right)$. Bentonite with activated carbon also has good sorption ability, although in this case the adsorption is affected by the properties of the activated carbon on the surface of the bentonite granules $\left(\mathrm{v}_{\text {corr }}=2.1 \times 10^{-3} \mathrm{~mm} \mathrm{a}^{-1}\right)$. Compared with activated alumina, bentonite alone has an order of magnitude greater corrosion rate of the resistometric lead probe $\left(\mathrm{v}_{\text {corr }}=3.0 \times 10^{-3} \mathrm{~mm} \mathrm{a} \mathrm{a}^{-1}\right)$. The least effective adsorbent of acetic acid vapours is zeolite; when it was used, the corrosion rate of the lead resistometric probe in acetic acid vapour environment was much greater $\left(\mathrm{v}_{\text {corr }}=1.1 \times 10^{-1} \mathrm{~mm} \mathrm{a}^{-1}\right)$ compared with the other tested adsorbents. According to Antonio Joao Cruz was a sorption ability of zeolite higher than was observed in
Table 3 The results of corrosion rate measurement of lead

\begin{tabular}{ll}
\hline Name & $\begin{array}{l}\text { Corrosion } \\
\text { rate of lead } \\
\left(\mathbf{m m ~ a ~}^{-1}\right)\end{array}$ \\
\hline Activated alumina & $3.7 \times 10^{-4}$ \\
Activated carbon & $1.5 \times 10^{-3}$ \\
Bentonite & $3.0 \times 10^{-3}$ \\
Bentonite with activated carbon & $2.1 \times 10^{-3}$ \\
Zeolite & $1.1 \times 10^{-1}$ \\
$\mathrm{RH}=100 \%+$ acetic acid vapours without using & $5.2 \times 10^{-1}$ \\
$\quad$ sorbents & $1.8 \times 10^{-2}$ \\
$\mathrm{RH}=100 \%$ without using sorbents &
\end{tabular}

this case $[25,26]$. The reason probably is that the commercial zeolite, which was used in this experiment, had smaller specific surface compared to the zeolite used by Antonio Joao Cruz. When an adsorbent was not used, the corrosion rate of the lead resistometric probe in acetic acid vapour environment equaled $\mathrm{v}_{\text {corr }}=5.2 \times 10^{-1}$ $\mathrm{mm} \mathrm{a}^{-1}$ and the lead measurement part of the probe was completely corroded already in 20 days. High humidity $\mathrm{RH}=100 \%$ in the absence of adsorbent is not aggressive towards lead and ensures passivation of the lead surface (Fig. 7, Table 3).

Results of resistometric probes show that the lowest lead corrosion rate in acetic acid vapour was measured when activated alumina was used. Very low corrosion rate of lead was also observed in the case of activated carbon. The specific surface area of activated alumina is comparable to that of activated carbon. Activated 


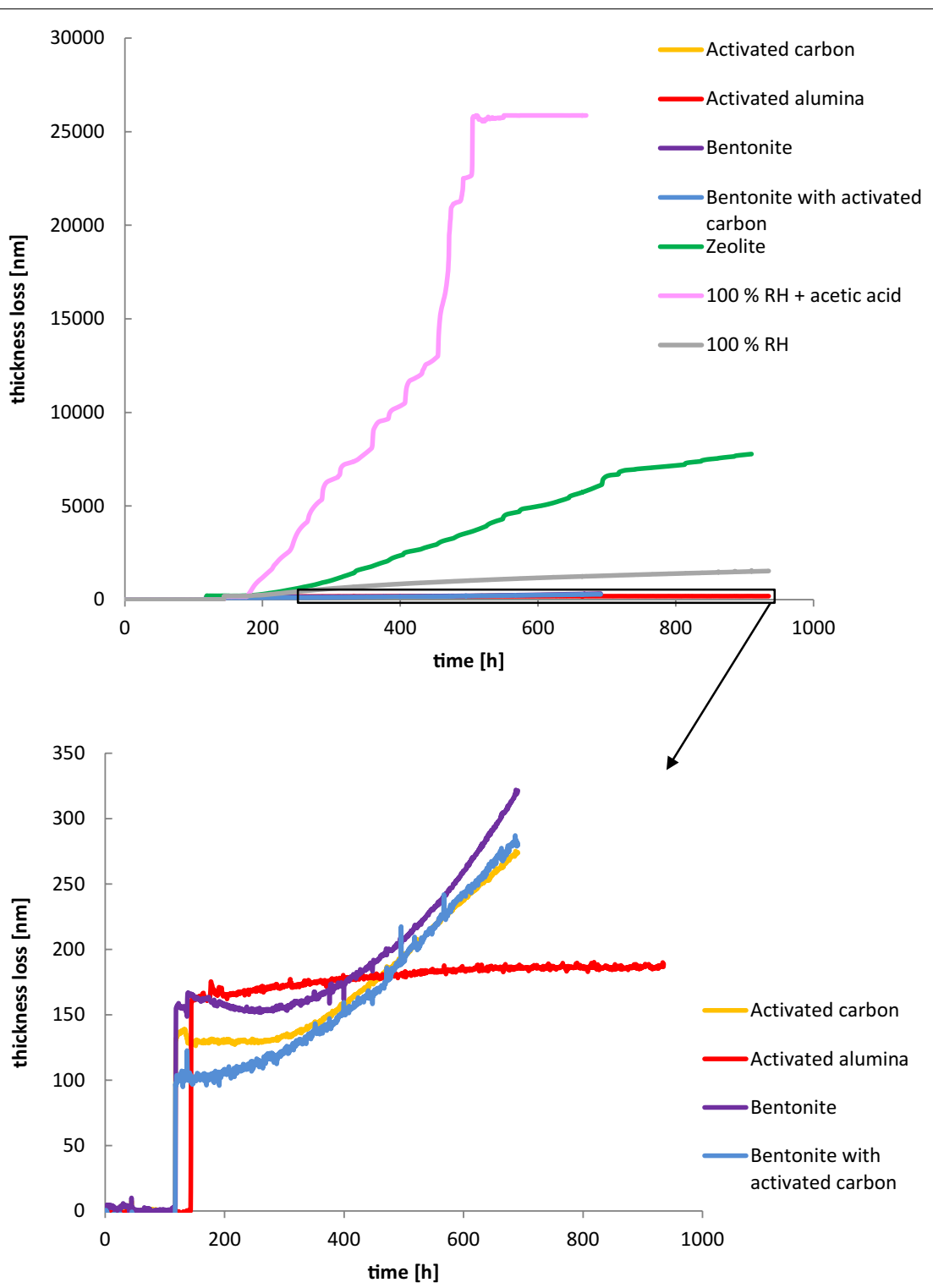

Fig. 7 Determination of the effectiveness of adsorbents in an acetic acid vapour environment using lead resistometric probes

alumina has a mesoporous structure with small amount of microspores whereas activated carbon has a microporous structure. Activated alumina is formed of elongated particles with an average length of $20 \mathrm{~nm}$ and $4-5 \mathrm{~nm}$ in diameter. On the other hand, activated carbon is formed of conglomerates of fine particles. The size of activated carbon conglomerates is in the range of tens to hundreds of micrometres. The difference in the microstructure of both adsorbents is one of the main reasons of better sorption capacity of activated alumina.
Commercial adsorbents-bentonite and zeolite, have significantly worse sorption properties in the acetic acid vapor environment compared to activated alumina and activated carbon. When using bentonite and zeolite, the lead corrosion rate in acetic acid vapour was much higher compared to activated alumina and activated carbon. The low sorption capacity of commercial adsorbents bentonite and zeolite is probably due to their small specific surface area. 


\section{Conclusion}

The characteristics of the tested adsorbents proved that the tested adsorbents activated carbon and activated alumina have the largest specific surface areas. Activated carbon is a material with major microporous structure. On the other hand, activated alumina is a material with major mesoporous structure. Bentonite is material with major mesoporous structure, but with a significantly smaller specific surface area compared to alumina. The used zeolite has the smallest specific surface area of all adsorbents tested. It follows from the results that the most effective adsorbent in acetic acid vapour environment is anion-active activated alumina. Non-ionic activated carbon has comparable effectiveness. Cation-active zeolite exhibited the worst sorption ability in the acetic acid vapour environment in the given experimental setup.

\section{Abbreviations}

BET: Brunauer-Emmett-Teller method; $A_{(s p)}$ : specific surface; $v_{\text {corr: }}$ corrosion rate; $\mathrm{RH}$ : relative humidity; r: pore radius.

\section{Acknowledgements}

The authors gratefully acknowledge the financial support by the Czech Ministry of Culture under NAKI II programme No. DG16P02R040.

\section{Authors' contributions}

SM (main author) interpreted the resistometric probes data. MK and JS managed the resistometric test. SCHK contributed in writing of the manuscript introduction. KP and PD prepared the lead samples and probes for resistometric test. ML analysed the specific surface area of adsorbents. All authors read and approved the final manuscript.

\section{Funding}

The financial support of NAKI II (project DG16P02R040) is gratefully acknowledged.

\section{Availability of data and materials}

The dataset analysed during the current study are available from the corresponding author on request.

\section{Competing interests}

The authors declare that they have no competing interests.

Received: 29 April 2019 Accepted: 14 September 2019

Published online: 26 September 2019

\section{References}

1. Pecenová Z, Kouřil M. Protection of historical lead against acetic acid vapour. Koroze a ochrana materiálů. 2016;60(1):28-34.

2. Leygraf Ch, Wallinder IO, Tidblad J, Graedel T. Atmospheric corrosion. 2nd ed. New Jersey: Wiley; 2016.

3. Graedel TE. Chemical mechanism for the atmospheric corrosion of lead. J Electrochem Soc. 1994;141(4):922-7.

4. Niklasson A, Johansson LG, Svensson JE. Atmospheric corrosion of lead: the influence of formic and acetic acid vapors. J Electrochem Soc. 2007;154(11):C618-25.
5. Selwyn L. Metals and corrosion: a handbook of conservation professional. 1st ed. Ottawa: Canadian Conservation Institute; 2004.

6. Coles EL, Cibson JG, Hinde RM. The corrosion of lead by dilute aqueous organic acid. J Appl Chem. 1958;8:341-8.

7. Abd-El Rehim S, Amin NH, Ali LI, Mohamed NF. Electrochemical behavior and corrosion of lead in some carboxylic acid solutions. J Chem Technol Biotechnol. 1998;72:197-201.

8. Niklasson A, Johansson LG, Svensson JE. The influence of relative humidity and temperature on the acetic acid vapour-induced atmospheric corrosion of lead. Corros Sci. 2008;50:3031-7.

9. Tétreault J, Sirois J, Stamatopoulou E. Studies of lead corrosion in acetic acid environments (artifact preservation). Stud Conserv. 1998;43:17-32.

10. Edwards R, Bordass W, Farrell D. Determination of acetic acid and formic acid in lead corrosion products by ion-exchange chromatography. Analyst. 1997;12:1517-20.

11. Raychaudhuri MR, Brimblecombe P. Formaldehyde oxidation and lead corrosion. Stud Conserv. 2000;45:226-32.

12. Ryhl-Svendsen M. Corrosivity measurements of indoor museum environments using lead coupons as dosimeters. J Cult Herit. 2008;9:285-93.

13. Niklasson A, Johansson LG, Svensson JE. Influence of acetic acid vapor on the atmospheric corrosion of lead. J Electrochem Soc. 2005;152(12):B519-25.

14. Sastri VS. Vapor phase corrosion inhibitors: in corrosion inhibitors principles and aplications. 1st ed. Chichester: Wiley; 1998. p. 787-822.

15. Strachotova KC, Kouril M, Kuchtakova K, Msallamova S. Inhibition efficiency of sodium salts of carboxylic acids on corrosion of lead in archive environment. Koroze a ochrana materiálů. 2019:63(1):37-47.

16. Parmar S, Grosjean D. Sorbent removal of air pollutants from museum display cases. Environ Int. 1991;17:39-50.

17. Decker K, Renjith SP, Nouar F, Pires J, Steunou N, Dumas E, Maurin G, Saerre $\mathrm{CH}$, Pinto ML. Metal-organic frameworks for cultural heritage preservation: the case of acetic acid removal. ACS Appl Mater Interfaces. 2018;10:13886-94.

18. Moore WJ. Physical chemistry. 4th ed. New Jersey: Prentice-Hall Inc.; 1972.

19. Rudzinski D, Everet DH. Adsorption of gases on heterogeneous surface. San Diego: Academic Press Ltd.; 1992.

20. Ladavos AK, Katsoulidis AP, losifidis A, Triantafyllidis KS, Pinnavaia TJ, Pomonis PJ. The BET equation, the inflection points of $\mathrm{N}_{2}$ adsorption isotherms and the estimation of specific surface area of porous solids. Microporous Mesoporous Mater. 2012;151:126-33.

21. Giesche H. Mercury porosimetry: a general (practical) overview. Part Part Syst Charact. 2006:23:9-19.

22. Kouril M, Prosek T, Dubus M, Taube M, Hubert V, Scheffel B, Degres Y, Jouannic M, Thierry D. Corrosion monitoring in the hands of restorers and conservators. Koroze a ochrana materiálů. 2012;3:67-75.

23. Msallamova S, Kouril M, Strachotova KC, Stoulil J, Popova K, Dvorakova P. Historical lead seals and the influence of disinfectants on the lead corrosion rate. Herit Sci. 2019;7(18):1-8.

24. Alothman YA. A review: fundamental aspects of silicate mesoporous materials. Materials. 2012;5:2874-902.

25. Cruz AJ, Pires J, Carvalho AP, Carvalho MB. Comparison of adsorbent materials for acetic acid removal in showcases. J Cult Herit. 2008.9.244-52

26. Cruz AJ, Pires J, Carvalho AP, Carvalho MB. Adsorption of acetic acid by activate carbons, zeolites, and other adsorbent material related with the preventive conservation of lead objects in museum showcases. J Chem Eng Data. 2004;49:725-31.

\section{Publisher's Note}

Springer Nature remains neutral with regard to jurisdictional claims in published maps and institutional affiliations. 